\title{
Estimation of Bcl-2 and Ki-67 in Gingival Epithelium of Epileptic Patients
}

\author{
Mohamed Helmy Salama ${ }^{1,2 *}$, Abdelraheem R. Algendy ${ }^{2,3}$, Saleem Shaikh ${ }^{4}$
}

\begin{abstract}
Introduction: Gingival overgrowth is one of several oral side effects of phenytoin, a potent antiepileptic drug. Several mechanisms have been elucidated to understand the pathogenesis of drug-induced gingival overgrowth. The frequency of gingival overgrowth associated with chronic phenytoin therapy remains controversial. Moreover, the possible subclinical effects of this drug on the gingival epithelium should be investigated histopathologically and immunohistochemically. Purpose of the Study: The purpose of the study was to investigate the Bcl-2 for apoptosis rate and Ki-67 for the epithelial proliferative activity in epileptic patients. Materials and Methods: Twenty-four samples of gingival tissue from epileptic patients treated with phenytoin and in eight samples of gingival tissue from healthy patients who did not use phenytoin (control) were evaluated for Bcl-2 and Ki-67 immunohistochemically. Results: The results revealed more proliferative activity of the overlying epithelium and an increased pattern of $\mathrm{Bcl}-2$ and $\mathrm{Ki}-67$ in phenytoin users compared to controls. Conclusion: These results concluded that the increased epithelial thickness observed in phenytoin-induced gingival overgrowth is associated with increased apoptotic rate and mitotic activity, especially in the oral epithelium.
\end{abstract}

Keywords: Bcl-2, Gingival overgrowth, Ki-67, Phenytoin

Asian Pac. J. Health Sci., (2020); DOI: 10.21276/apjhs.2020.7.3.13

\section{INTRODUCTION}

Gingival enlargement or overgrowth is the increase in size of the gingiva that caused by a variety of etiologic factors, including inflammation, adverse events, systemic diseases, genetic and neoplastic or false enlargement, as well as certain medications. ${ }^{[1-10]}$ Drug-induced gingival overgrowth (DIGO) is an important side effect of prolonged intake certain drugs, such as anticonvulsants (phenytoin) immunosuppressants (cyclosporine) and calcium channel blockers (nifedipine). ${ }^{[11-16]}$ Although these medications are usually associated with the development of gingival overgrowth, they continue to be the drugs of choice for the prevention of epileptic seizures, transplant rejection, and hypertension, respectively. ${ }^{[17-20]}$ The mechanisms whereby drugs with different pharmacological actions induce different types of gingival overgrowth with relatively similar clinical and histopathological characteristics remain a matter of debate. ${ }^{[11,13,15-19]}$

Some studies proposed that DIGO could be induced by rupture of homeostasis between synthesis and degradation of collagen and other extracellular matrix components, as well as between cell proliferation and apoptosis involving the gingival epithelium and connective tissue. ${ }^{[21-26]}$ Other series realized that the pathogenesis of DIGO has been related to the presence of a genetically determined subpopulation of drugsensitive fibroblasts, which may respond by increasing cell proliferation/survival or by altering the synthesis and remodeling of extracellular matrix. ${ }^{[27-32]}$ In an attempt to better understand the pathogenesis of phenytoin as a DIGO, the present study evaluates the immunohistochemical expression of antiapoptotic protein $\mathrm{BCl}-2$ and the cell proliferation rates (Ki-67) in gingival overgrowth of epileptic patients using phenytoin and compared the findings with those observed for clinically healthy gingiva. In addition, the associations with histopathological features will establish.
'Department of Periodontology, College of Dentistry, Majmaah University, KSA

${ }^{2}$ Department of Periodontology, College of Dentistry, Al-Azhar University, Cairo, Egypt

${ }^{3}$ Specialist, King Fahd Specialized Hospital, Buraydah, KSA

${ }^{4}$ Department of Maxillofacial Surgery and Diagnostic Sciences, College of Dentistry, Majmaah University, KSA

Corresponding Author: Mohamed Helmy Salama, College of Dentistry, Majmaah University, KSA. Phone: +966598322035. E-mail: helmysalama @hotmail.com

How to cite this article: Salama MH, Algendy AR, Shaikh S. Estimation of $\mathrm{BCl}-2$ and $\mathrm{Ki}-67$ in Gingival Epithelium of Epileptic Patients. Asian Pac. J. Health Sci., 2020; 7(3):53-58

Source of support: Nil

Conflict of interest: None

Received: 05/05/2020 Revised:20/06/2020 Accepted:09/07/2020

\section{Materials and Methods}

\section{Study Cases}

This retrospective study was conducted with the epileptic patients who had been referred for the management of their periodontal problems at the outpatient clinics of the Periodontology Department, Faculty of Dentistry, Al-Azhar University, Cairo, Egypt, during the period between $2015 \mathrm{G}$ and 2018G. Twenty-four male patients were included in this study, ranging in ages from 15 to 35 years after obtaining approval from the university ethical committee and informed consent was obtained from the patient after thoroughly explaining the advantages and disadvantages of treatment procedures.

Gingival biopsies were collected from 24 epileptic subjects who had receiving phenytoin with moderate-to-severe gingival overgrowth during gingivectomy procedures. Normal healthy

(c)2020 The Author(s). This is an open access article distributed under the terms of the Creative Commons Attribution License (http:// creativecommons.org/ licenses/by/4.0/), which permits unrestricted use, distribution, and reproduction in any medium, provided the original work is properly cited. 
gingival tissue samples without clinical signs of periodontal inflammation were also included as control samples. The control gingival tissue samples were taken from the marginal gingiva of eight patients of the same gender and age when they underwent routine dental treatment (e.g., tooth extraction for orthodontic reasons or crown lengthening procedures). The control subjects were recruited from the outpatient clinic at the Faculty of Dentistry, Al-Azhar University, Cairo, Egypt, during the same period. All patients signed a consent form after being advised of the nature of the study. Diagnosis was based on the detailed patients' history and careful clinical examination, Figure $1 \mathrm{a}$ and $\mathrm{b}$ and Figure 2.

\section{Tissue Processing}

Gingival tissue samples of the 24 epileptic patients and the 8 control subjects were fixed in $10 \%$ formalin and embedded in paraffin. Sections with $4 \mu \mathrm{m}$ thickness were cut at the central region of each specimen to obtain maximum standardization of the cutting surface. Serial sections were taken from tissue blocks and processed for morphological and immunohistochemical examination. One section from each sample was stained with hematoxylin and eosin to evaluate the histopathological presentation of gingival enlargement in epileptic patients and normal gingival tissue in control samples.

\section{Immunohistochemical Staining}

Sections were deparaffinized in xylene and alcohol and rehydrated in graded alcohols. Slides were boiled in citrate buffer $(\mathrm{pH} \mathrm{6.0)}$ at $95-100^{\circ} \mathrm{C}$ for $5 \mathrm{~min}$ and were cooled down for $20 \mathrm{~min}$. Endogenous peroxide was blocked by $3 \%$ hydrogen peroxide in methanol for $10 \mathrm{~min}$. Sections were incubated with $\mathrm{Bcl}-2$ monoclonal antibody (1:200, DAKO, Carpinteria, CA, USA) and a mouse anti-human Ki-67
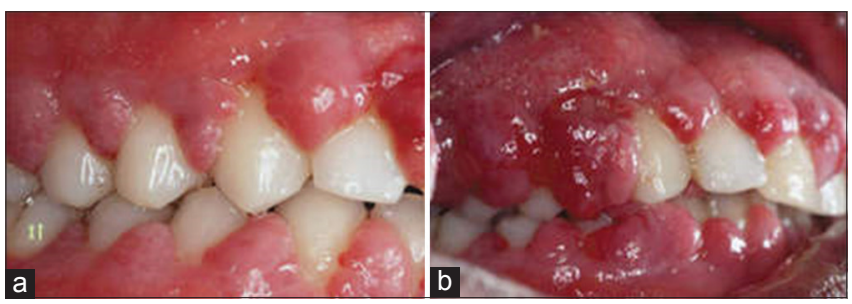

Figure 1: Clinical view of epileptic patients with moderate (a) and severe (b) gingival overgrowth, respectively

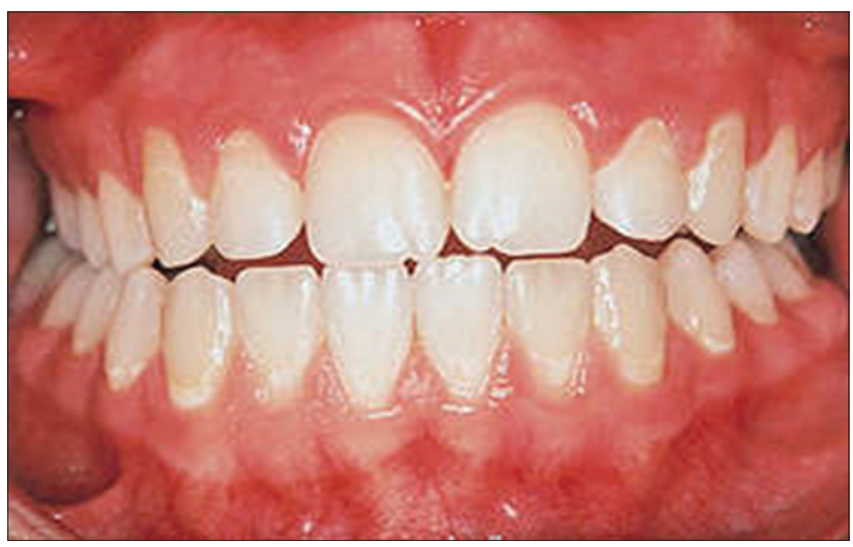

Figure 2: Clinical view of normal healthy gingival tissue antibody (Zymed, CA, USA) for $1 \mathrm{~h}$ at $37^{\circ} \mathrm{C}$, immunohistochemical staining. The chromogen substrate for the development of the peroxidase activity was 3,3-diaminobenzidine (DAKO, Cytomation, Carpinteria, CA, USA). All sections were counter stained with Meyer's hematoxylin. The sections processed without the primary antibodies were used as negative control. Each step was followed by thorough washes with phosphate-buffered saline.

\section{Evaluation of Immunostaining}

Ordinary light microscope was first used to detect and localize the positive and negative $\mathrm{BCl}-2$ and $\mathrm{Ki}-67$ immunostaining reaction within the gingival tissues in 10 representative fields for all $\mathrm{Bcl}-2$ and Ki-67 stained specimens. Epithelial cells of the gingival tissue with nuclear brown staining were considered positive, while negative immune reaction showed no brown staining.

\section{Statistical Analysis}

The obtained immunohistochemical results of all examined sections were given as mean values \pm standard deviation for statistical evaluation. Chi-square test and Pearson correlation analysis were used to compare the overall expression of different proteins among the examined gingival tissue specimens. Differences were considered statistically significant when $P<0.05$.

\section{Results}

\section{Histopathological and Immunohistochemical Findings}

The histopathological features of the normal healthy tissue samples exhibited parakeratinized overlying epithelium with normal thickness and slightly elongated epithelial ridges extending into the underlying connective tissue layers. The connective tissue stroma showed normal amount of collagen fibers interspersed with variable numbers of fibroblasts and fibrocytes and some blood vessels, as well as few chronic inflammatory cell infiltrate, Figure 3.

Examination of $\mathrm{H}$ and $\mathrm{Estained} \mathrm{sections} \mathrm{of} \mathrm{moderate} \mathrm{and} \mathrm{severe}$ cases of DIGO of epileptic patients revealed histopathological features that did not differ greatly between different cases.

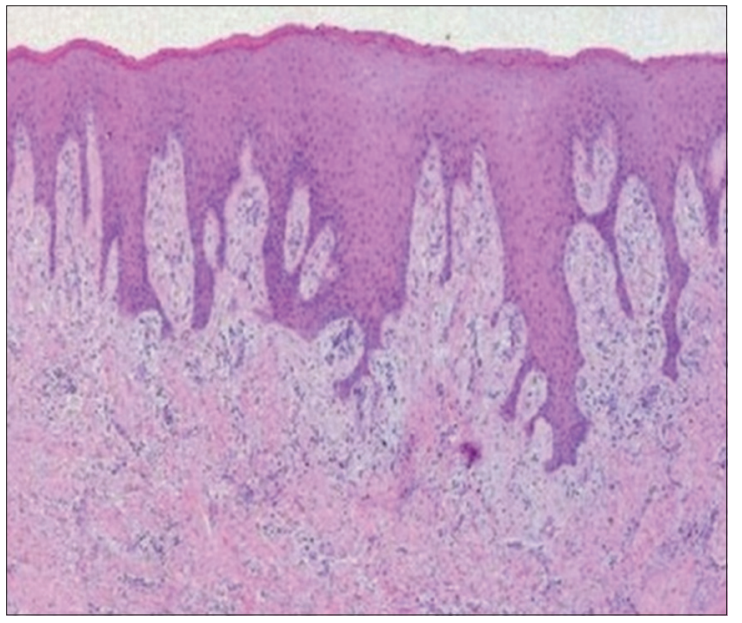

Figure 3: Histopathology of normal gingival tissues showing normal overlying epithelium and connective tissue $(\mathrm{H}$ and $\mathrm{E} \times 100)$ 
They shared a common histopathology of a significant papillary hyperplasia of the overlying epithelium and thick parakeratinized epithelial layer. Acanthosis and deep anastomosing epithelial ridges penetrating into the underlying connective tissue were also noted.

The underlying connective tissue stroma manifested an increased amount of collagen fiber bundles and few number of fibroblasts and fibrocytes, in addition to limited number of chronic inflammatory cell infiltrates, Figure 4.

Immunohistochemical examination of healthy control gingival tissues observed weak $\mathrm{Bcl}-2$ and $\mathrm{Ki}-67$-positive cells only in the basal and parabasal layers of the covering epithelium, while lamina propria showed negative immunostaining of $\mathrm{BCl}-2$ and $\mathrm{Ki}-67$ monoclonal antibodies, Figure $5 \mathrm{a}$ and $\mathrm{b}$. While the overgrowing gingival tissue of epileptic patients revealed a strong, positive, nuclear immunostaining pattern of $\mathrm{BCl}-2$ and $\mathrm{Ki}-67$ widely distributed throughout the overlying epithelial layers, in the control gingival tissues it was mainly located in the basal and suprabasal layers of the covering epithelium with no difference in density of staining affinity as illustrated in Figure $6 a$ and b. This positive reaction was more noticeable within epithelial cells than the connective tissue cells. In the lamina propria, $\mathrm{Bcl}-2$ and $\mathrm{Ki}-67$ expressions were observed in fibroblasts of hyperplastic gingival tissues only.

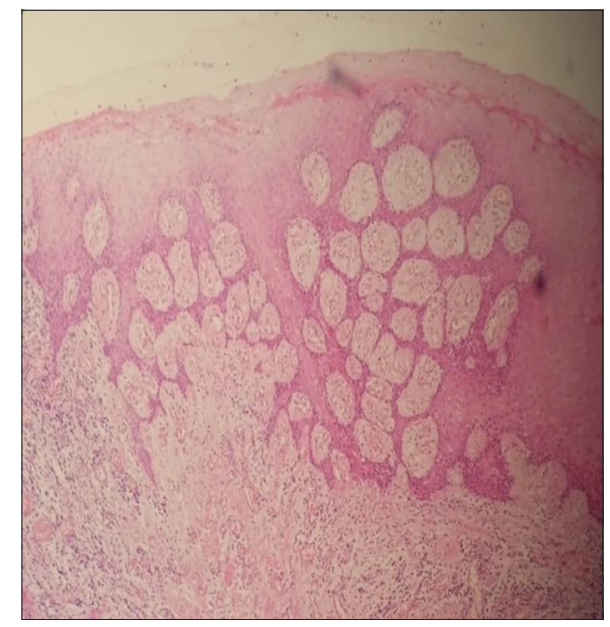

Figure 4: Histopathological picture of phenytoin-induced gingival overgrowth showing hyperplastic epithelium and elongated slender rete processes. The connective tissue shows excessive collagen fiber

bundles with little chronic inflammatory cells ( $\mathrm{H}$ and $\mathrm{E} \times 100)$



Figure 5: ( $\mathrm{a}$ and b) Ki-67 and $\mathrm{Bcl}-2$ antigen-positive nuclei observed mainly in the basal and suprabasal layer of control gingival epithelium (Streptavidin-Biotin, $\times 100$ )

\section{Statistical Analyses}

Histopathological and immunohistochemical results of this work, as well as Chi-square test, revealed that gingival overgrowth of epileptic patients was correlated proportionally with $\mathrm{Bcl}-2$ and Ki-67 expression. Thus, immunohistochemical expression was significantly high in gingival tissue of epileptic patients. No significant correlation was identified between $\mathrm{Bcl}-2$ and $\mathrm{Ki}-67$ expression and healthy control gingival tissues [Table 1 and Figure 7].

\section{Discussion}

DIGO, also referred to as drug-induced gingival enlargement, and previously referred to as drug-induced gingival hyperplasia, is a noted side effect of more than 15 drugs that have been identified as possible causative agents of gingival overgrowth. However, phenytoin is more commonly involved. ${ }^{[1-15]}$ Not all patients using phenytoin are affected by gingival overgrowth, however, the prevalence rate of drug-induced enlargement was reported to vary

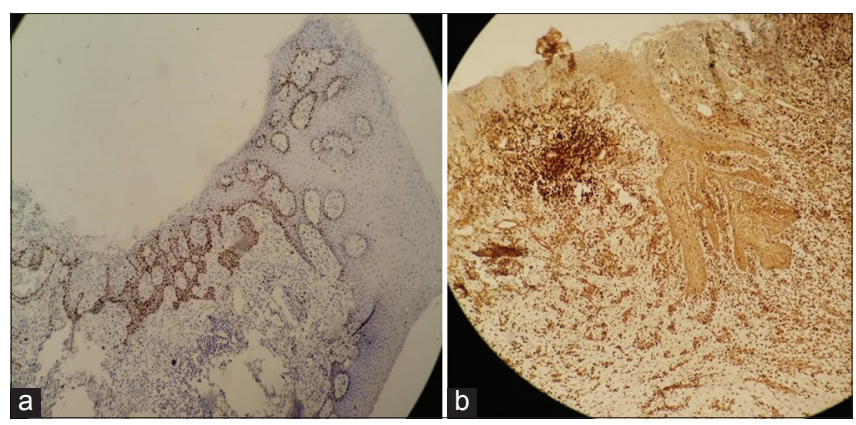

Figure 6: ( $\mathrm{a}$ and b) $\mathrm{Ki}-67$ and $\mathrm{Bcl}-2$ antigen-positive cells throughout the gingival tissues of epileptic patients (Streptavidin-Biotin, $\times 100$ )

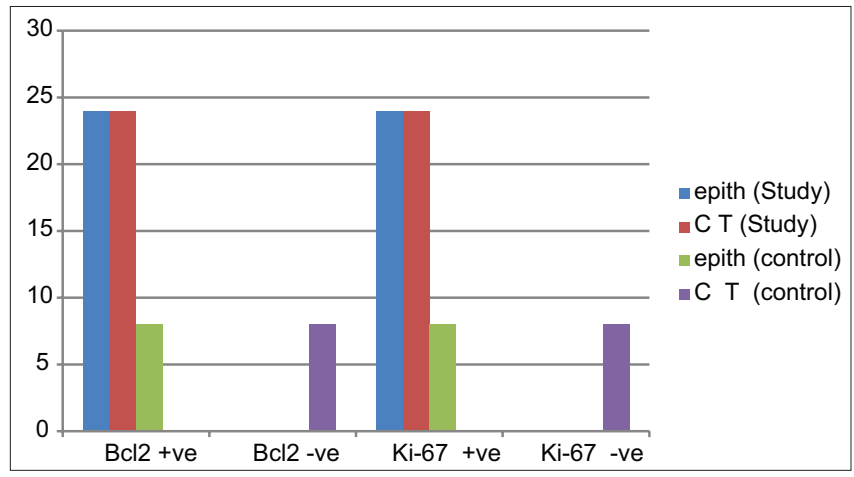

Figure 7: Histogram showing comparison between $\mathrm{BCl}-2$ and $\mathrm{Ki}-67$ immunoreactivity in study and control cases

Table 1: Comparison between $\mathrm{BCl}-2$ and $\mathrm{Ki}-67$ expression in epithelium and connective tissue of study and control cases

\begin{tabular}{lccccc}
\hline Variables & \multicolumn{2}{c}{ Number of study cases } & & \multicolumn{2}{c}{ Number of control cases } \\
\cline { 2 - 3 } \cline { 5 - 6 } & Epith. & $C T$ & & Epith. & CT \\
\hline $\mathrm{Bcl}_{2}+$ +ve & 24 & 24 & & 8 & 0 \\
$\mathrm{Bcl}_{2}$-ve & 0 & 0 & & 0 & 8 \\
$\mathrm{Ki}-67+$ ve & 24 & 24 & & 8 & 0 \\
$\mathrm{Ki}-67$-ve & 0 & 0 & & 0 & 8 \\
$P$ value & 0.01 & 0.01 & & 0.05 & 0.05 \\
\hline
\end{tabular}

$P$-value $0.014^{*} 0.7470 .006^{*} 0.003^{*},{ }^{*}$ significant at $P \leq 0.05$ 
from $10 \%$ to $15 \%$ for phenytoin. ${ }^{[33]}$ Furthermore, gender and age may not be relevant risk factors for phenytoin-induced overgrowth than other drugs. ${ }^{[34]}$ A correlation with dosage, duration, drug concentrations (in blood and whole saliva), and severity extent of gingival enlargement has also been suggested, but so many variables (sampling technique and pharmacokinetic factors) can influence this aspect that it remains controversial. ${ }^{[35-39]}$ However, it has been recently reported that patients treated with phenytoin solution experience earlier onset of gingival changes and more extensive overgrowth than patients using capsules. ${ }^{[36-38]}$

Clinically, phenytoin-induced gingival overgrowth usually starts from the papillary regions. As the process develops, the papillae increase in size and the margins and gingival attachment may also became involved. The anterior segments and the labial gingiva are most commonly involved, but the enlargement may also be observed in the molar regions, particularly in the late stages of disease, in which the gingivae are firm and pale because of the conspicuous fibrous component. ${ }^{[39-44]}$ Some case reports have also described overgrowth of edentulous ridges and elsewhere. ${ }^{[45]}$

The pathogenesis of DIGOs is still not completely understood. It has been demonstrated that gingival enlargement has a multifactorial nature and is affected by factors such as age, demographic variables, genetic predisposition, oral hygiene status, pharmacokinetic variables, and molecular and cellular changes in gingival tissues. ${ }^{[46-52]}$ Phenytoin can influence the metabolism of some age-dependent hormones (i.e., testosterone) which could have a direct effect on gingival cells populations. ${ }^{[53]}$ Changes in gingival contour seen in DIGO may also be exacerbated by plaque-induced gingival inflammation, through a mechanism of mechanical and chemical chronic irritation. ${ }^{[5,55]}$

In the present study, the obtained histopathological results of phenytoin-induced gingival overgrowth revealed a marked acanthosis, parakeratosis of the covering epithelium with thin elongated processes extended toward the connective tissue stroma. The underlying connective tissue showed an increased amount of collagen fiber bundles, few number of fibroblasts and fibrocytes, and some blood vessels, in addition to limited number of chronic inflammatory cell infiltrates, Figure $3 a$ and $b$.

These results were in agreement with the microscopic results of many previous studies concerning the effect of prolonged intake of phenytoin on the gingival tissue of epileptic patients. ${ }^{[56-62]}$ The current results could be attributed to the increased production of collagen and protein leading to excessive formation of extracellular matrix and collagen fibers with reduction of collagenase activity. ${ }^{[63]}$ Moreover, increased levels of interleukin- 6 and transforming growth factor- $b$ and the decreased levels of gamma-interferon observed during prolonged intake of phenytoin therapy may help the fibroblast synthesis of collagen fibers. ${ }^{[64,65]}$ Similarly, other studies showed complex interactions between the drug or phenytoin, gingival tissues, and local released mediators. ${ }^{[56-62]}$ Finally, the exact mechanism underlying the development of gingival overgrowth due to phenytoin ingestion is still unclear until now. ${ }^{[6-65]}$

On the light of the aforementioned clinical and histopathological findings of the current study, proliferation of gingival tissue of epileptic patients receiving phenytoin and subsequent an increased cell division was confirmed. However, several factors, including age, genetic predisposition, pharmacokinetic variables, and plaque-induced inflammatory changes, are believed to be important in the onset and severity of gingival overgrowth. Thus, the possible role of phenytoin for enhancement the proliferative activity of gingival tissue in epileptic patients was investigated immunohistochemically using $\mathrm{BCl}-2$ and $\mathrm{Ki}-67$ monoclonal antibodies.

$\mathrm{BCl}-2$ (B-cell lymphoma 2), encoded in humans by the $\mathrm{Bcl} 2$ gene, is the founding member of the $\mathrm{Bcl}-2$ family of regulator proteins that control programmed cell death (apoptosis), by either inducing (pro-apoptotic) or inhibiting (anti-apoptotic) apoptosis. $^{[66-70]} \mathrm{Bcl}-2$ is localized to the outer membrane of mitochondria, where it plays an important role in promoting cellular survival and inhibiting the actions of pro-apoptotic proteins. It is still not clear what biochemical activity of $\mathrm{BCl}-2$ is responsible for its function, but increasing evidence indicates that a functional activity of $\mathrm{BCl}-2$ on the endoplasmic reticulum (ER) protects mitochondria under diverse circumstances. ${ }^{[69]}$ Indeed, an emerging hypothesis is that, during apoptosis, the $\mathrm{Bcl}-2$ family regulates ER-to-mitochondrion communication by $\mathrm{BH} 3$-only proteins and calcium ions and thereby triggers mitochondrial dysfunction and cell death. ${ }^{[68,70,71]}$ Finally, overexpressed $\mathrm{Bcl}-2$ contributes to transformation of cells by preventing them from undergoing apoptosis, as seen in B-cell lymphomas, in which Bcl-2 is upregulated following a chromosomal translocation. ${ }^{\text {[72] }}$

An increasing evidence indicated that an unusual cell proliferation may have a role in the pathogenesis of gingival overgrowth with different etiologies, including administration of certain drugs, such as phenytoin. The best-known antibody that recognizes the proliferating cells or activity of gingival tissue of epileptic patients administered phenytoin is $\mathrm{Ki}-67$ monoclonal antibody. Ki-67 is a proliferation associated antigen that serves as a marker for estimation of tissue growth as it is present in the nuclei of proliferating cells located in G1, S, G2, and M phases of the cell cycle and absent in quiescent cells lagging in G0 phase, suggesting a role for $\mathrm{Ki}-67$ in the early steps of rRNA synthesis. ${ }^{[73-77]}$

Concerning the immunohistochemical results, all the examined samples of normal gingival tissues of this study showed Bcl-2 as scattered positive cells in between the basal cells of normal gingival epithelium. This reflects the progenitor cell role of basal cells, which require the protection of $\mathrm{Bcl}-2$ against apoptotic cell death to ensure survival of the entire epithelium. Its absence in the suprabasal layers indicates that $\mathrm{Bcl} 2$ is not required during completion of the differentiation process. ${ }^{[78]}$ Moreover, weak positive staining with $\mathrm{Ki}-67$ was detected in the basal and suprabasal layers of normal gingival epithelium while lamina propria showed negative immunostaining of the same antibody. This finding explained the physiological proliferative activity that always exists in the basal and suprabasal layers of the normal gingival epithelium. ${ }^{[79]}$

On the other hand, the immunohistochemical findings of gingival tissue of epileptic patients revealed a strong, positive, nuclear immunoreactivity of $\mathrm{BCl}-2$ and $\mathrm{Ki}-67$ throughout the epithelial cells of the covering epithelium, but mostly in the basal and suprabasal layers. While, the connective tissue showed positive expression in fibroblasts of hyperplastic gingival tissues. This result showed a significant proliferative potential of epithelium and connective tissue of epileptic gingival tissue as reflected byBcl-2 and Ki-6 immunoreactivity which was higher than control tissues. In agreement with this result, Nurmenniemi et al. ${ }^{[80]}$ also reported a significant increase in numbers of Ki-67-labeled cells in phenytoininduced gingival hyperplasia cases compared to healthy controls. Saito et al. ${ }^{[81]}$ found that mean rates of Ki-67-positive cells in 
phenytoin gingival overgrowth patients were significantly higher as well than healthy tissues. Saygun et al., ${ }^{[82]}$ who suggested that the underlying mechanism of high gingival fibrosis does not involve increased cellular proliferation of the epithelium and the gingival overgrowth is caused by excessive extracellular matrix deposition.

\section{Conclusion}

The previously mentioned findings of this study confirmed that increased expression of $\mathrm{BCl}-2$ and $\mathrm{Ki}-67$ may have a role in the pathogenesis of gingival overgrowth induced by prolonged intake of phenytoin. Accordingly, further studies with larger sample size will provide more conclusive data on the possible role of enhanced proliferative activity of cells in the pathogenesis of gingival overgrowth. Finally, more studies are needed to determine whether epileptic patients on phenytoin are at high risk of the development of neoplasms or not.

\section{References}

1. Lin K, Guilhoto LM, Yacubian EM. Drug-induced gingival enlargementPart II. Antiepileptic drugs: Not only phenytoin is involved. J Epilepsy Clin Neurophysiol 2007;13:83-8.

2. Wright G, Welbury RR, Hosey MT. Cyclosporin-induced gingival overgrowth in children. Int J Paediatr Dent 2005;15:403-11.

3. Boltchi FE, Rees TD, lacopino AM. Cyclosporine a-induced gingival overgrowth: A comprehensive review. Quintessence Int 1999;30:775-83.

4. Euvard S, Kanitakis J, Claudy A. Skin cancers after organ transplantation. N Engl J Med 2003;348:1681-91.

5. Spolidorio LC, Spolidorio DM, Massucato EM, Neppelenbroek KH, Campanha $\mathrm{NH}$, Sanches $\mathrm{MH}$. Oral health in renal transplant recipients administered cyclosporin a or tacrolimus (FK506). Oral Dis 2006;12:309-14.

6. Cockfield SM. Identifying the patient at risk for post-transplant lymphoproliferative disorder. Transpl Infect Dis 2001;3:70-8.

7. Proctor R, Kumar N, Stein A, Moles D, Porter S. Oral and dental aspects of chronic renal failure. J Dent Res 2005;84:199-208.

8. Varga E, Tyldesley WR. Carcinoma arising in cyclosporin-induced gingival hyperplasia. Br Dent J 1991;171:26-7.

9. McLoughlin P, Newman L, Brown A. Oral squamous cell carcinoma arising in phenytoin-induced hyperplasia. Br Dent J 1995;178:183-4.

10. Penn I. Depressed immunity and the development of cancer. Cancer Detect Prev 1994;18:241-52.

11. Pramod S, Vijay K, Tanguturi S, Rachakonda H. Drug-induced gingival overgrowth: A critical insight into case reports from over two decades. J Indian Soc Periodontol 2016;20:496-502.

12. El Firt EY, Ghalwash DM. Ki-67 expression in gingival overgrowth: An immunohistochemical study. Life Sci J 2011;8:221-6.

13. Diop S, Letestu R, Orsolani D, Leboeuf Y, Le Tutour P, Thiam D, et al. Expression of proliferation marker $\mathrm{Ki} 67$ in chronic lymphocytic leukemia. Dakar Med 2005;50:65-8.

14. Buduneli N, Buduneli E, Cxınar S, Lappin D, Kinane DF. Immunohistochemical evaluation of Ki-67 expression and apoptosis in cyclosporin a-induced gingival overgrowth. Periodontology 2007;78:282-9.

15. Kee N, Sivalingam S, Boonstra R, Wojtowicz JM. The utility of Ki-67 and BrdU as proliferative markers of adult neurogenesis. J Neurosci Methods 2002;115:97-105.

16. Schluter C, Duchrow M, Wohlenberg C, Becker MH, Key G, Flad HD, Gerdes J. The cell proliferation-associated antigen of antobody Ki-67: A very large, ubiquitous nuclear protein with numerous repeated elements, representing a new kind of cell cycle-maintaining proteins. J Cell Biol 1993;123:513-22.
17. Saito K, Mori S, Tanda N, Sakamoto S. Expression of p53 protein and Ki-67 antigen I gingival hyperplasia induced by nifedipine and phenytoin. J Periodontol 1999;70:581-6.

18. Ananthanarayanan V, Deaton RJ, Yang XJ, Pins MR, Gann PH. Alteration of proliferation and apoptotic markers in normal and premalignant tissue associated with prostate cancer. BMC Cancer 2006;6:73.

19. Fulda S, Debatin KM. Extrinsic versus intrinsic apoptosis pathways in anticancer chemotherapy. Oncogene 2006;25:4798-811.

20. Jones ML. Connective tissue and stains. In: Bancroft JD, Gamble M, editors. Theory and Practice of Histological Techniques. $5^{\text {th }}$ ed. Philadelphia, PA: Churchill Livingstone; 2002. p. 531-9.

21. Aimetti M, Romano F, Marsico A, Navone R. Non-surgical periodontal treatment of cyclosporin a-induced gingival overgrowth: Immunohistochemical results. Oral Dis 2008;14:244-50.

22. Kantarci A, Augustin P, Firatli E, Sheff MC, Hasturk H, Graves DT, et al. Apoptosis in gingival overgrowth tissues. J Dent Res 2007;86:888-92.

23. Abdollah $M$. Current opinion on drug-induced oral reactions: $A$ comprehensive review. J Contemp Dent Pract 2008;9:1-15.

24. Schincaglia GP, Forniti F, Cavallini R, Piva R, Calura G, del Senno L. Cyclosporin-a increases Type I procollagen production and mRNA level in human gingival fibroblasts in vitro. J Oral Pathol Med 1992;21:181-5.

25. Li LL, Yin YZ, Wu ZK, Shi YJ. Expression of TGF-b1 and PCNA in cyclosporine A-induced gingival overgrowth. Shanghai Kou Qiang Yi Xue $2011 ; 20: 131-5$.

26. Brunet L, Miranda J, Roset P, Berini L, Farre M, Mendieta C. Prevalence and risk of gingival enlargement in patients treated with anticonvulsant drugs. Eur J Clin Invest 2001;31:781-8.

27. Nurmenniemi PK, Pernu HE, Knuuttila ML. Mitotic activity of keratinocytes in nifedipine-and immunosuppressive medicationinduced gingival overgrowth. J Periodontol 2001;72:167-73.

28. Das SJ, Newman HN, Olsen I. Keratinocyte growth factor receptor is up-regulated in cyclosporin a-induced gingival hyperplasia. J Dent Res 2002;81:683-7.

29. Myrillas TT, Linden GJ, Marley JJ, Irwin CR. Cyclosporin a regulates interleukin-1beta and interleukin-6 expression in gingiva: Implications for gingival overgrowth. J Periodontol 1999;70:294-300.

30. Tüter G, Serdar M, Yalim M, Gürhan IS, Balos K. Evaluation of matrix metalloproteinase-1 and tissue inhibitor of metalloproteinase-1 levels in gingival fibroblasts of cyclosporin a-treated patients. J Periodontol 2002;73:1273-8.

31. Chong SA, Lee W, Arora PD, Laschinger C, Young EW, Simmons CA, et al. Methylglyoxal inhibits the binding step of collagen phagocytosis. J Biol Chem 2007;282:8510-20.

32. Humayun S, Prasad VR. Expression of p53 protein and Ki-67 antigen in oral premalignant lesions and oral squamous cell carcinomas: An immunohistochemical study. Natl J Maxillofac Surg 2011;2:38-46.

33. Vooijs GP. Benign proliferative reactions, intraepithelial neoplasia and invasive cancer of the uterine cervix. In: Bibbo B, editor. Comprehensive Cytopathology. Philadelphia, PA: W.B. Saunders; 1991. p. 153-230.

34. Yoshida T, Nagata J, Yamane A. Growth factors and proliferation of cultured rat gingival cells in response to cyclosporin a. J Periodont Res 2005;40:11-9.

35. Cetinkaya BO, Acikgoz G, Aydin O, Korkmaz A, CayirKeles G. The relationship between proliferating cell nuclear antigen expression and histomorphometrical alterations in cyclosporin a-induced gingival overgrowth in rats. Toxicol Pathol 2006;34:180-6.

36. Tu HP, Chen YT, Shieh YS, Chin YT Huang RY, Yang SF, et al. Cyclosporininduced downregulation of the expression of E-cadherin during proliferation of edentulous gingival epithelium in rats. J Periodontol 2006;77:832-9.

37. Hyland PL, Mckeown ST, Mackenzie IC, Irwin CR. Regulation of keratinocyte growth factor and scatter factor in cyclosporin-induced gingival overgrowth. J Oral Pathol Med 2004;33:391-7.

38. Buduneli N, Sağol O, Atilla G, Duman S, Holmstrup P. 
Immunohistochemical analysis of epidermal growth factor receptor in cyclosporine induced-gingival overgrowth. Acta Odontol Scand 2001;59:367-71.

39. Bulut S, Ozdemir BH. Apoptosis and expression of caspase-3 in cyclosporin-induced gingival overgrowth. J Periodontol 2007;78:2364-8.

40. Willershausen-Zönnchen B, Lemmen C, Schumacher U. Influence of cyclosporine a on growth and extracellular matrix synthesis of human fibroblasts. J Cell Physiol 1992;152:397-402.

41. Cotrim P, Martelli-Junior H, Graner E, Sauk JJ, Coletta RD. Cyclosporin a induces proliferation in human gingival fibroblasts via induction of transforming growth factor-beta1. J Periodontol 2003;74:1625-33.

42. Deepa P, Visakan J. Cyclosporine a: Novel concepts in its role in druginduced gingival overgrowth. Dent Res J (Isfahan) 2015;12:499-506.

43. Modéer T, Domeij $H$, Andurén I, Mustafa M, Brunius G. Effect of phenytoin on the production of interleukin- 6 and interleukin-8 in human gingival fibroblasts. J Oral Pathol Med 2000;29:491-9.

44. Sato $\mathrm{N}$, Matsumoto $\mathrm{H}$, Akimoto $\mathrm{Y}$, Fujii $A$. The effect of $\mathrm{IL}-1 \alpha$ and nifedipine on cell proliferation and DNA synthesis in cultured human gingival fibroblasts. J Oral Sci 2005;47:105-10.

45. Sakagami G, Sato E, Sugita Y, Kosaka T, Kubo K, Maeda H, et al. Effects of nifedipine and interleukin-1 alpha on the expression of collagen, matrix metalloproteinase-1, and tissue inhibitor of metalloproteinase-1 in human gingival fibroblasts. J Periodontol Res 2006;41:266-72.

46. Nishikawa S, Nagata T, Morisaki I, Oka T, Ishida H. Pathogenesis of drug-induced gingival overgrowth. A review of studies in the rat model. J Periodontol 1996;67:463-71.

47. Niimi A, Tohnai I, KanedaT,Takouchi M, Nagura H.Immunoistochemical analysis of effects of cyclosporin a on gingival epithelium. J Oral Pathol Med 1990;19:397-403.

48. TerHarmsel B, Smadts F, Kuupers J, Jeunnk M, Trimbost B, Ramaekers F. $\mathrm{Bcl}-2$ immunoreactivity increases with severity of CIN: A study of normal cervical epithelia, CIN, and carcinoma. J Pathol 1996;197:26-30.

49. Jung JY, Jeong YJ, Jeong TS, Chung HJ, Kim WJ. Inhibition of apoptotic signals in overgrowth of human gingival fibroblasts by cyclosporin a treatment. Arch Oral Biol 2008;53:1042-9.

50. Bulut S, Ozdemir BH, Alaaddinoglu EE, Oduncuoglu FB, Bulut $\mathrm{OE}$, Demirhan B. Effect of cyclosporin a on apoptosis and expression of p53 and BCl-2 proteins in the gingiva of renal transplant patients. J Periodontol 2005;76:691-5.

51. Alaaddinoglu EE, Karabay $G$, Bulut $S$, Oduncuoglu FB, Ozdemir $H$, Bulut $\mathrm{OE}$, et al. Apoptosis in cyclosporin a-induced gingival overgrowth: A histological study. J Periodontol 2005;76:166-70.

52. Birraux J, Kirby JA, Thomason JM, Taylor JJ. The effect of cyclosporin on cell division and apoptosis in human oral keratinocytes. J Periodont Res 2006;41:297-302.

53. Romito GA, Lotufo RF, Saraiva L, Pustiglioni AN, Pustiglioni FE, Stolf NA. Superinfecting microorganisms in patients under treatment with cyclosporin-a and its correlation to gingival overgrowth. Pesqui Odontol Bras 2003;17:35-40.

54. Strasser A, Harris AW, Bath ML, Cory S. Novel primitive lymphoid tumours induced in transgenic mice by cooperation between myc and bcl-2. Nature 1990;348:331-3.

55. Vaux DL, Cory S, Adams JM. Bcl-2 gene promotes haemopoietic cell survival and cooperates with c-myc to immortalize pre-B cells. Nature 1988;335:440-2.

56. Nakopoulou L, Vourlakou C, Zervas A, Tzonou A, Gakiopoulou H, Dimopoulos MA. The prevalence of $\mathrm{BCl}-2$, p53, and Ki-67 immunoreactivity in transitional cell bladder carcinomas and their clinicopathologic correlates. Hum Pathol 1998;29:146-54.

57. Maitu E, Sato M, Yamaki K. Effect of tranilast on martin metalloproteinase-1 secretion from human gingival fibroblast in vitro. J Periodontol 2004;75:1054-60.

58. Brunet L, Miranda J, Fere M, Berini L, Mendieta C. Gingival enlargement induced by drugs. Drug Saf 1996;15:219-31.

59. Gronzalez O, Gonzalez JM. Morphological and phenotypic difference in fibroblasts obtained from gingival overgrowth secondary to phenytoin: Pilot study. Rev Odontol Mex 2009;13:17-23.

60. Perucca E. An introduction to antiepileptic drugs. Epilepsia 2005;46:31-7.

61. Lucches J, Cortelli SH, Rodrigues J. Server phenytoin-induced gingival enlargement associated with periodontitis. Gen Dent 2008;56:199-203.

62. Reynolds EH. Chronic antiepileptic toxicity, a review. Epilepsia 1975;16:319-52

63. Bhatia A, Prakash S. Topical phenytoin for wound healing. Dermatol Online J 2004;10:5.

64. Doufexi A, Mina M, Loannidou E. Gingival overgrowth in children: Epidemiology, pathogenesis and complications, a literature review. J Periodontol 2005;76:3-10.

65. Morisaki KK, Loyola-Rodriguez JP, Nagata T, Ishida H. Nifediphineinduced gingival overgrowth in the presence or absence of gingival inflammation in rats. J Period Res 1993;28:396-403.

66. Ishikawa S, Nagata T, Morisaki I, Oka T, Ishida H. Pathogenesis of drug induced gingival over-growth, a review of studies in the rat model. J Periodontol 1996;67:463-71.

67. Seymour RA, Heasann PA. Drugs and the periodontium. J Clin Periodontol 1992;19:1-11.

68. Hassel TM, Hefti AF. Drug induced gingival overgrowth: Old problem, new problem. Crit Rev Oral Biol Med 1991;2:103-7.

69. Barclay S, Thomason TM, Idle JR, Seymour RA. The incidence and severity of nifediphine induced gingival overgrowth. J Clin Periodontol 1992;19:311-4.

70. Seymour RA, Thomason JM, Ellis JS. The pathogenesis of drug induced gingival overgrowth. J Clin Periodontol 1996;23:165-75.

71. Easley J. Methods of determining alveolar osseous form. J Periodontol 1967;38:112.

72. Friedman N. Periodontal osseous surgery, osteoplasty and osteoectomy. J Periodontol 1955;26:257.

73. Goldman HM, Cohen DW. The infrabony pocket: Classification and treatment. J Periodontol 1958;29:272.

74. Ochsenbein C. A primer for osseous surgery. Int J Period Restor Dent 1986;6:9.

75. Carranza FA, Take H, Newman M. Clinical Periodontology. $10^{\text {th }}$ ed. Philadelphia, PA: W.B. Saunders Co.; 2006. p. 18, 63, 270-2, 920-2.

76. Guncu GN, Caglayan F, Dincel A, Bozkurt A, Sayg S, Karabulut E. Plasma and gingival curricular fluid phenytoin concentrations as risk factors for gingival overgrowth. J Periodontol 2006;77:2005-10.

77. Seymour R. Effects of medications on the periodontal tissues in health and disease. J Periodontol 2006;40:120-9.

78. Yamada H, Nishimura F, Naruishi K, Chou H, Takashiba SH. Phenytoin and cyclosporine a suppress the expression of MMP-1, TTMP-1 and cathepsin, but not cathepsin B in cultured gingival fibroblasts. J Periodontol 2000;71:955-60.

79. Kataoka M, Kido J, Shinohara Y, Nagata T. Drug-induced gingival overgrowth-a review. Biol Pharm Bull 2005;28:1817-21.

80. Nurmenniemi PK, Pernu HE, Knuuttila ML. Mast cell subpopulations in gingival overgrowth induced by immunosuppressive and nifedipine medication. J Periodontol 2004;75:933-8.

81. Saito K, Mori S, Iwakura M, Sakamoto S. Immunohistochemical localization of transforming growth factor beta, basic fibroblast growth factor and heparansulphate glycosaminoglycan in gingival hyperplasia induced by nifedipine and phenytoin. J Period Res 1996;31:545-55.

82. Saygun I, Ozdemir A, Gunhan O, Aydintug YS, Karslioglu Y. Hereditary gingival fibromatosis and expression of Ki-67 antigen: A case report. J Periodontol 2003;74:873-8. 